\title{
PERSISTENT LACTATION ASSOCIATED WITH HIGH OESTROGEN EXCRETION AND CYSTIC OVARIES IN A WOMAN WITH A PREVIOUS HISTORY OF A CHROMOPHOBE ADENOMA OF THE PITUITARY
}

\author{
J. W. JULL, * W. R. HENDERSON AND R. V. SHORT \\ Department of Experimental Pathology and Cancer Research, \\ University of Leeds; The General Infirmary, Leeds; \\ Agricultural Research Council Unit of Reproductive Physiology and Biochemistry, \\ Department of Veterinary Clinical Studies, University of Cambridge
}

(Received 8th November 1963)

\begin{abstract}
Summary. A case is described in which a woman with a previous history of a pituitary chromophobe adenoma subsequently developed persistent lactation and dysmenorrhoea.

Abnormally high levels of oestrogen excretion were found to be associated with cystic ovaries and uterine fibromas. Steroid concentrations in the ovarian cyst fluid are presented, together with hormone excretion data for periods previous and subsequent to hysterectomy and bilateral salpingo-oophorectomy.
\end{abstract}

\section{INTRODUCTION}

Animal experiments have shown that the hormonal factors concerned in the initiation and maintenance of lactation are extremely complex (Cowie, 1961). Human lactation following parturition is associated with a fall in oestrogen excretion (Brown, 1956) and in paralactation not associated with suckling the clinical data usually suggest low oestrogen levels (Bonser, Dossett \& Jull, 1961). In the human, lactation rarely occurs in circumstances where a high oestrogen level might be expected.

The following case report is of special interest in relation to the hormonal factors controlling lactation in the human and the aetiology of pituitary chromophobe adenoma and ovarian cysts.

\section{CASE REPORT}

The patient, aged 31 years, a married nulliparous woman, had menstruated regularly from the age of 13 years until about 1 year prior to examination when her periods became irregular and scanty, the intervals varying from 2 to 6 weeks, with an interval of 3 months on one occasion. The duration varied between 1 and 5 days.

Six months before examination on the 4th March 1959, there had been

* Present address: Cancer Research Centre, University of British Columbia, Vancouver 8, B.C., Canada. 
blurring of vision with frontal headaches. Examination revealed bitemporal hemianopia with blurring of vision in the paracentral region of the right eye. There was some pallor of the left disc. There was no other abnormality of the central nervous system. Blood pressure was 160/100. Radiographically there was slight enlargement of the pituitary fossa.

On the 7th April 1959, the pituitary fossa was exposed revealing a tumour the size of a cherry, which was stretching both optic nerves. The capsule was diathermized and incised and the interior of the tumour evacuated, leaving the capsule. The tumour was found microscopically to be a pituitary chromophobe adenoma composed of cuboidal or columnar epithelial cells with slightly foamy or clear cytoplasm, uniform in size and with no detectable mitoses.

Postoperatively there were one or two fits for which Largactil (100 mg p.r.n.) was administered for about a week. No Largactil was given subsequently. Luminal, $\frac{1}{2}$ gr b.d. was given for 2 months. A course of radiotherapy was given between the 11 th June and 1st July 1959, to a total dose of $4500 \mathrm{r}$.

There was amenorrhoea until December 1959 when frequent slight bleeding commenced lasting for 2 or 3 days at a time. This was treated on one occasion with norethisterone ( $5 \mathrm{mg}$ b.d.) until the bleeding temporarily ceased. Sporadic bleeding continued for the next 21 months.

Extremely slight infrequent discharge from the nipples commenced about 6 months after the pituitary operation but was not apparently related to the vaginal discharge or norethisterone therapy. In June 1961 the breasts enlarged and the discharge from the nipples became more copious, requiring the changing of pads twice a day and at night. The patient denied any positive effort at manual expression. The secretion was white and contained lactose $2.4 \%$, alkaline phosphatase 42 King-Armstrong units, protein $5 \%$ and numerous fat globules. Apart from the rather low figure for lactose this approximates to the normal values for human milk.

Gynaecological examination on the 13th September 1961 disclosed no ovarian tumour but thickening of the vaginal vault on the left with irregular cragginess of the rectovaginal septum. As irregular vaginal bleeding continued hysterectomy with bilateral salpingo-oophorectomy was performed on the 16th December 1961.

The uterus was large and in the muscular wall were seven fibromyomas, the largest being $1.5 \mathrm{~cm}$ in diameter. Glands were scanty in the endometrium and were of a non-secreting simple tubular type. The stromal cells were swollen, with pale nuclei, and appeared to be undergoing a pseudodecidual reaction. The stroma was heavily infiltrated with polymorphs.

Each ovary measured $7 \times 3 \times 6 \mathrm{~cm}$ and contained eight or nine smooth-walled cysts measuring from a few $\mathrm{mm}$ to $3 \mathrm{~cm}$ diameter (Pl. 1, Fig. 1). Between the cysts and covering them was much firm pale pink or white homogeneous tissue, that on the surface was dense and wrinkled. On microscopical examination there were bundles of spindle cells between the cysts. These showed occasional mitoses and were considered to be theca cells. When stained for fat variable numbers of fine sudanophil droplets were seen in these cells. Their diffuse disposition in and around the cysts led to a diagnosis of thecal cell hyperplasia rather than neoplasia. 
PLATE

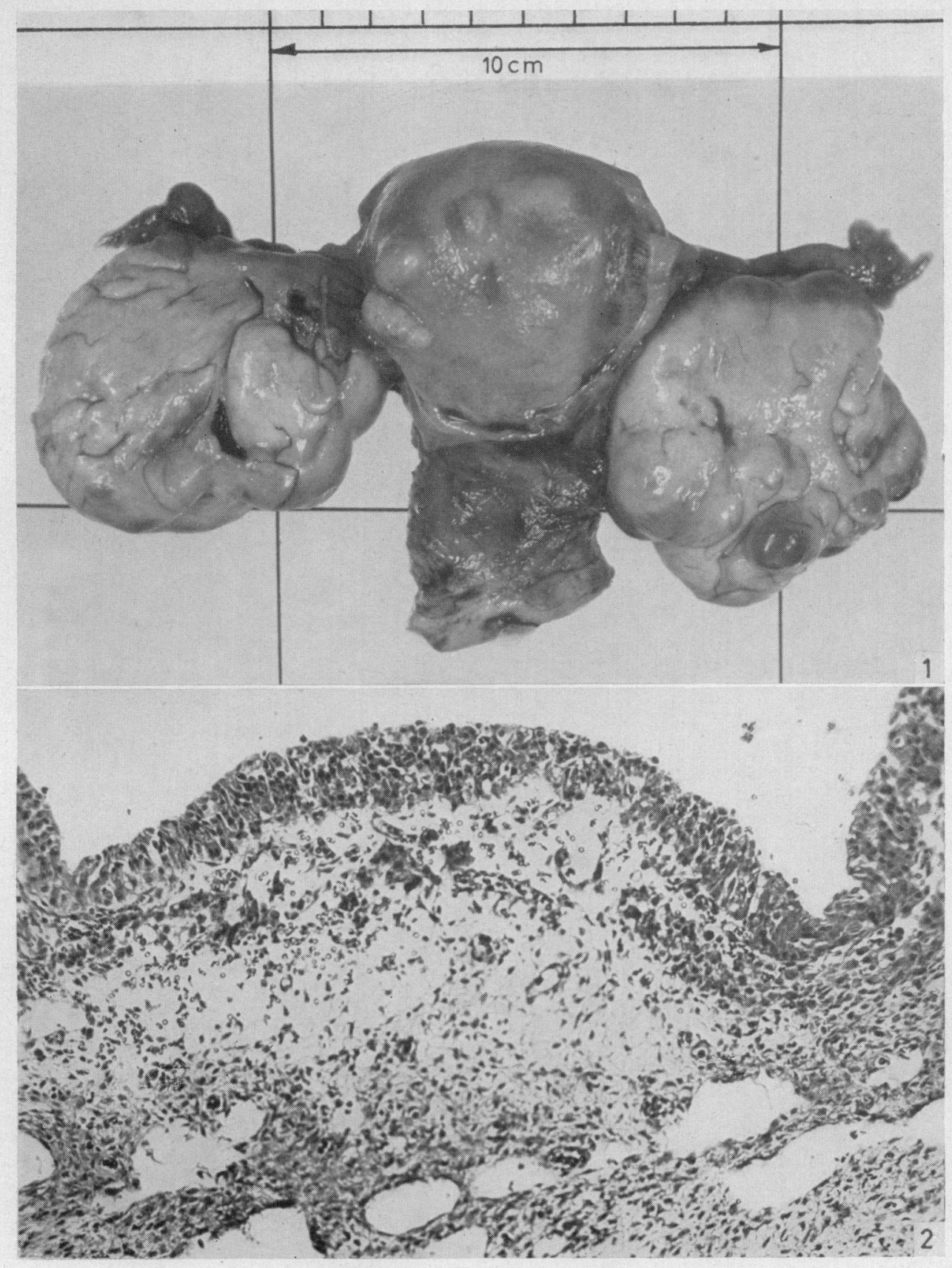

FIG. 1. Gross specimen of uterus and ovaries immediately after removal.

Fic. 2. Section of cyst wall. Haematoxylin and $\operatorname{cosin} . \times 90$.

(Facing p. 368) 
Occasional degenerate primordial follicles were present in the ovaries but no ripening follicles. The cysts were lined chiefly by luteinized granulosa cells six to ten layers thick with a well-developed and vascular theca interna (Pl. 1, Fig. 2). Cyst fluid was aspirated and stored at $-20^{\circ} \mathrm{C}$ until analysed.

The progress of the patient since hysterectomy has been generally uneventful. Lactation diminished during the first 2 or 3 weeks but then progressively increased in amount until about the 8th week, since when it has varied in amount from time to time, but persists 18 months after oophorectomy. There has been no evidence of recurrence of the pituitary ademona since it was removed.

TABLE 1

24-HR URINARY HORMONE EXGRETION

\begin{tabular}{|c|c|c|c|c|c|c|c|c|}
\hline Date & $\begin{array}{c}\text { Oestriol } \\
(\mu g)\end{array}$ & $\begin{array}{l}\text { Oestrone } \\
(\mu g)\end{array}$ & $\begin{array}{c}\text { Oestradiol } \\
(\mu g)\end{array}$ & $\begin{array}{l}\text { Pregnane- } \\
\text { diol } \\
(m g)\end{array}$ & $\begin{array}{l}\text { Pregnane- } \\
\text { triol } \\
\quad(m g)\end{array}$ & $\begin{array}{l}\text { 17-Keto- } \\
\text { steroids } \\
(\mathrm{mg})\end{array}$ & $\begin{array}{l}\text { 17-Keto- } \\
\text { genic } \\
\text { steroids } \\
(\mathrm{mg})\end{array}$ & $\begin{array}{c}\text { Urinary } \\
\text { gonado- } \\
\text { trophins } \\
\text { (mouse units) }\end{array}$ \\
\hline $\begin{array}{l}18.8 .61 \\
19.8 .61 \\
20.8 .61 \\
21.8 .61 \\
22.8 .61 \\
23.8 .61 \\
25.8 .61 \\
26.8 .61 \\
27.8 .61 \\
28.8 .61\end{array}$ & $\begin{array}{l}43 \cdot 8 \\
23 \cdot 2 \\
35 \cdot 6 \\
\\
14 \cdot 4 \\
13 \cdot 6 \\
43 \cdot 2 \\
27 \cdot 0 \\
28 \cdot 8 \\
79 \cdot 3\end{array}$ & $\begin{array}{r}114 \cdot 5 \\
59 \cdot 1 \\
86 \cdot 2 \\
18 \cdot 9 \\
19 \cdot 2 \\
43 \cdot 2 \\
140.9 \\
152 \cdot 3 \\
142 \cdot 8\end{array}$ & $\begin{array}{r}21 \cdot 4 \\
12 \cdot 4 \\
23 \cdot 5 \\
\\
4 \cdot 8 \\
3 \cdot 3 \\
12 \cdot 6 \\
25 \cdot 7 \\
33 \cdot 1 \\
32 \cdot 1\end{array}$ & $\begin{array}{l}0.5 \\
3.2 \\
0.6 \\
\\
\\
1.4 \\
\\
\\
\\
\\
0.4\end{array}$ & $2 \cdot 8$ & $\begin{array}{l}4 \cdot 9 \\
6 \cdot 0 \\
3 \cdot 1\end{array}$ & 1.9 & 6 \\
\hline 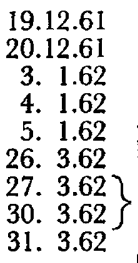 & $\begin{array}{l}10 \cdot 6 \\
4 \cdot 6 \\
1 \cdot 1 \\
0 \\
0 \\
\\
1 \cdot 4 *\end{array}$ & $\begin{array}{l}1 \cdot 0 \\
1.0 \\
1 \cdot 7 \\
4 \cdot 0 \\
1.0 \\
\\
4 \cdot 0 *\end{array}$ & $\begin{array}{l}0 \\
0 \\
3 \cdot 0 \\
0 \\
0 \\
\\
\\
0^{*}\end{array}$ & & & & & $\begin{array}{l}10 \\
32\end{array}$ \\
\hline
\end{tabular}

Hysterectomy with bilateral salpingo-oophorectomy was carried out on 16th December 1961.

* Pooled urine.

\section{HORMONE ESTIMATIONS}

\section{METHODS}

Twenty-four-hr urine specimens were stored at $-20^{\circ} \mathrm{C}$ until analysed. Oestriol, oestrone and oestradiol were measured by the method of Brown, Bulbrook \& Greenwood (1957) pregnanediol and pregnanetriol were measured by the method of Leon \& Bulbrook (1960), 17-ketosteroids by the method of Drekter, Heisler, Scism, Stern, Pearson \& McGavack (1952) and 17-ketogenic steroids by the method of Norymberski, Stubbs \& West (1953). Urinary gonadotrophins were measured by the method of Loraine \& Brown (1956); gonadotrophin assays were made by the Sheffield and Region Endocrine Investigation Centre. 
Steroids in the ovarian cyst fluid were analysed by the methods described by Short (1961a, b).

\section{RESULTS}

Urinary hormone estimations are listed chronologically in Table 1. Before hysterectomy the upper limits of oestrogen excretion were much greater than have been recorded in non-pregnant women and are comparable with what might be expected in cases of adrenal or ovarian tumour. Although the pregnanediol values of 3.2 and $2.6 \mathrm{mg}$ were similar to those found in the luteal phase of the menstrual cycle the remaining values were low and there was no suggestion of the typical peak found in normally menstruating women. The values for pregnanetriol and 17-keto and 17-ketogenic steroids were within normal limits.

After oophorectomy the levels of oestrogen and pregnanediol excretion have remained within the range normally found in post-menopausal women. The urinary gonadotrophin levels are rather low in the normal range.

TABLE 2

CONGENTRATIONS OF STEROIDS IN $7 \cdot 2$ ML GYST

FLUID REMOVED FROM OVARIES

\begin{tabular}{l|c}
\hline \multicolumn{1}{c|}{ Steroid } & Concentration $(\mu \mathrm{g} / 100 \mathrm{ml})$ \\
\hline Pregnenolone & Not detected $(<0 \cdot 7)$ \\
Progesterone & $278 \cdot 0$ \\
17@-Hydroxyprogesterone & 203.0 \\
Androstenedione & $66 \cdot 8$ \\
Dehydroepiandrosterone & 19.5 \\
Testosterone & Not detected $(<1.4)$ \\
Oestrone & $11 \cdot 1$ \\
Oestradiol-17 & $178 \cdot 0$ \\
Oestriol & Not detected $(<0 \cdot 7)$ \\
& \\
\hline
\end{tabular}

The steroid concentration in the ovarian cyst fluid (Table 2) should be compared with the results published by Short \& London (1961). The concentrations of progesterone, $17 \alpha$-hydroxyprogesterone and oestradiol-17 $\beta$ are higher than normal.

\section{DISCUSSION}

It is not possible to decide whether the cystic ovaries were the cause or the consequence of the pituitary adenoma, or even if the two conditions were in any way related. The sharp fall in oestrogen excretion after oophorectomy leaves no doubt that the ovaries were the source of the oestrogens. It is difficult to understand why lactation was not initiated until about 6 months after removal of the pituitary tumour, and why it did not cease after oophorectomy. One possible explanation is that some of the pituitary adenoma was left behind at the time of the original operation, and that it subsequently started to produce gonadotrophins and prolactin. This possibility is entirely conjectural, and there is not much evidence to support it. For example, the urinary gonadotrophin 
levels in this patient were always within the normal range, and there was no clinical evidence to suggest the reappearance of a pituitary tumour.

It is conceivable that the primary lesion might even have been an oestrogensecreting ovarian tumour. It is well known that prolonged administration of oestrogens to rats and mice will induce the development of prolactin-secreting pituitary tumours, which in turn cause lactation (Meyer \& Clifton, 1956). Such tumours can induce mammary gland development and lactation when transplanted to castrated, adrenalectomized male rats given cortisol (Clifton \& Furth, 1960). Although the ovaries in this patient were enlarged, and histologically presented the appearance of a thecoma, there was no evidence of any abnormality in the pattern of steroid synthesis, as judged by the cyst fluid analysis. The concentrations of progesterone, 17 $\alpha$-hydroxyprogesterone and oestradiol-17 $\beta$ were high, but did not greatly exceed the normal values. The histological evidence suggests that the steroids were being produced by the luteinized granulosa cells and vascular theca interna cells lining the cyst (see Pl. 1, Fig. 2) rather than by the hypertrophied spindle cells of the thecoma itself. It is interesting to note that a small amount of dehydroepiandrosterone was detected in the cyst fluid, but this cannot be regarded as abnormal (Ryan \& Smith, 1961).

\section{ACKNOWLEDGMENTS}

We are grateful to many of our colleagues for their cooperation in the study of this case.

\section{REFERENCES}

Bonser, G. M., Dossetr, J. A. \& Jull, J. W. (1961) Human and experimental breast cancer. Pitman, London.

Brown, J. B. (1956) Urinary excretion of oestrogens during pregnancy, lactation, and the re-establishment of menstruation. Lancet, $\mathbf{i}, 704$.

Brown, J. B., Bulbrook, R. D. \& GreEnwood, F. G. (1957) An additional purification step for a method of estimating oestriol, oestrone and oestradiol-17 $\beta$ in human urine. $\mathcal{7}$. Endocrin. 16, 49.

Curton, K. H. \& Furth, J. (1960) Ducto-alveolar growth in mammary glands of adreno-gonadectomized male rats bearing mammatrophic pituitary tumours. Endocrinology, 66, 893.

CowIE, A. T. (1961) The hormonal control of milk secretion. Milk: The Mammary Gland and its Secretion, vol. I, p. 163. Ed. S. K. Kon and A. T. Cowie. Academic Press, New York.

Drekter, I. J., Heisler, A., Scism, G. R., Stern, S., Pearson, S. \& McGavack, T. H. (1952) Determination of urinary steroids. I. The preparation of pigment-free extracts and a simplified procedure for the estimation of total 17-ketosteroids. F. clin. Endocrin. 12, 55.

LEon, Y. A. \& BuLbrook, R. D. (1960) A modification of a method for the determination of urinary pregnanetriol. F. Endocrin. 20, 236.

Loraine, J. A. \& Brown, J. B. (1956) Further observations on the estimation of urinary gonadotrophins in non-pregnant human subjects. F. clin. Endocrin. 16, 1180.

MEYER, R. K. \& Clifton, K. H. (1956) Effect of diethylstilbestrol-induced tumorigenesis on the secretory activity of the rat anterior pituitary gland. Endocrinology, 58, 686.

Norymberski, J. K., Stubis, R. D. \& WEsT, H. F. (1953) Assessment of adrenocortical activity by assay of 17-ketogenic steroids in urine. Lancet, $\mathbf{i}, 1276$.

Ryan, K. J. \& Smith, O. W. (1961) Biogenesis of estrogens by the human ovary. 7. biol. Chem. 236, 2207.

SHORT, R. V. (1961a) Steroid concentrations in the follicular fluid of mares at various stages of the reproductive cycle. F. Endocrin. 22, 153.

Short, R. V. (1961b) $\Delta^{5} 3 \beta$-Hydroxy steroids in the follicular fluid of the mare. F. Endocrin. 23, 277.

SHORT, R. V. \& London, D. R. (1961) Defective biosynthesis of ovarian steroids in the Stein-Leventhal syndrome. Brit. med. F. i, 1724. 